\title{
ZRNO DO ZRNA POGAČA, KAMEN NA KAMEN (TURISTIČNA) PALAČA
}

\section{- nadnacionalna raba naravnih in kulturnih virov - temelj sonaravnega turističnega razvoja ob tromeji Italije, Avstrije in Slovenije}

\begin{abstract}
Anton Gosar*
Izvleček

$U D K 338.26: 379.8(450)+(436)+(497.4)$

Prispevek predstavi večnacionalni raziskovalni projekt, ki udejanja razvojni koncept t. i. "zidakov« v sonaravnem turističnem razvoju ob tromeji Avstrije, Italije in Slovenije. Opisuje obstoječo in nato sestavi možno celostno "pogačo" oziroma "hišo" turistične ponudbe na območju Tromeje. Opozarja na dejavnike, ki zavirajo sodelovanje, hkrati pa razčljenjuje enkratnosti stika treh svetovnih kultur in jezikov $v$ alpskem svetu. Podaja izbrane, za turizem pomembne naravne in kulturne sestavine pokrajine, imenujmo jih "zrnca" ali "kamenčke", ki lahko v kompleksni ponudbi oblikujejo okusno turistično pogačo oziroma trdno hišo turističnega gospodarstva v regiji ob Tromeji - v Ziljski, Kanalski, Savski in Soški dolini.
\end{abstract}

Ključne besede: Alpe, Avstrija, Italija, sonaravno načrtovanje, Tromeja, turizem

GRAIN BY GRAIN YIELDS BREAD, BRICK BY BRICK PRODUCES A (TOURIST) PALACE

Abstract

The following article presents results of a multi-national project focusing on the development of tourism, in accordance with the principles of sustainability in the Three border area of Austria, Italy and Slovenia. This area was the candidate for the Winter Olympics 2006. The paper registers tourist demand and offerings; through the concept of "bricklaying" the existing tourist attractions are glued together into one single tourist product. In particular the fact that this is an area where the Romance (Italian), Germanic (Austrian) and Slavonic (Slovenian) peoples and culture meet plays in important role in promotional and sustainable development aspects. History plays in important role as well.

Key words: The Alps, Austria, Italy, sustainable development, The Dreilaendereck-region, tourism

\footnotetext{
* Dr., redni univ. profesor, Oddelek za geografijo, Filozofska fakulteta, Univerza v Ljubljani, Aškerčeva cesta 2, SI-1001 Ljubljana in VŠHT - Visoka šola za hotelirstvo in turizem, Obala 29, SI - 6320 Portorož
} 


\section{UVOD}

Številni programi Evropske zveze, predvsem Phare in Interreg, podpirajo razvoj gospodarstev na obeh straneh zunanjih meja zveze. Območje Tromeje v Sloveniji, Italiji in Avstriji je od leta 1995 udeleženo $\mathrm{v}$ razvojnih programih Evropske zveze in kaže pet let kasneje dobre rezultate na področju kmetijstva (v Avstriji), infrastrukture (v Italiji) in komunale (Slovenija). Turistično gospodarstvo se je na ponujene možnosti, z izjemo turizma na kmetiji, le oprezno odzvalo. V Sloveniji so bili pogosti vzroki odlašanja nerešena lastniško-posestna vprašanja in pomanjkanje dolgoročnejših zasnov turističnega gospodarstva. Ob Tromeji je - zahvaljujoč predvsem posameznim pobudnikom - turizem upe stavil na nadnacionalno sodelovanje in $\mathrm{v}$ tem okviru na endogeni sonaravni razvoj, ki bi vključeval naravne in kulturne vire vseh treh držav hkrati. Na teh temeljih je bila zasnovana ideja o zimski olimpiadi Treh dežel (Koroške, Gorenjske in Furlanije-Julijske krajine). Letošnja kandidatura za olimpijske igre z imenom »Klagenfurt 2006« je obetala uspeh, saj so pravila olimpijskega komiteja sedaj naravnana tako, da omogočajo izvedbo tekmovanj tudi v sosednjih državah kandidatke. Sodelovanje v tem projektu je za območje Tromeje in njenega turizma pomembno ne le zaradi športne prireditve na svetovni ravni, pač pa predvsem zaradi predstavitve imena in obravnavane regije Vzhodnih Alp. Vstaviti svoje geografsko ime v paleto približno 600 svetovno znanih turističnih krajev oziroma regij je namreč izredno težavna naloga. Posebno še, ker so se ljudje in turistična gospodarstva ob Tromeji odločili, da bodo podpirali izključno tak turistični razvoj, ki bo temeljil na sonaravnih načelih.

Da bi podprla omenjeno idejo je avstrijska vlada ob tisočletnici obstoja države financirala raziskovalni projekt, ki bi presegel dosedanje načrtovanje in prostorsko organizacijo za potrebe olimpijade. V okviru t. i. koncepta zidakov kot temelja inovativnega turističnega razvoja (»Innovatives Tourismus-Baustein-Konzept im Dreilaendereck Italien, Slowenien, Oesterreich«) je raziskava želela popisati obstoječo in sosledno sestaviti novo, celostno "stavbo" turistične ponudbe na območju Tromeje. Pričujoči zapis želi v grobem prikazati osnovne značilnosti projekta in pojasniti nekatere dejavnike, ki pospešujejo oziroma zavirajo turizem v gorskem svetu nasploh, prednostno pa na območju Tromeje. Hkrati želi opozoriti na naravne in kulturne sestavine pokrajine, imenujmo jih zrnca ali kamenčke, ki naj v prihodnje oblikujejo okusno turistično pogačo oziroma trdno hišo turizma oziroma gospodarstva ob Tromeji - v Sloveniji, Avstriji in Italiji.

Pri obravnavi omenjene kompleksne, nadnacionalne raziskave ne moremo mimo tistih, ki so jo oblikovali. Poleg nosilcev projekta profesorjev Andreasa Moritscha s celovške in Friedricha Zimmermanna $\mathrm{z}$ graške univerze, so pri projektu, ob avtorju, sodelovali še Mojca Dolgan - Petrič in Boštjan Gradišar z Oddelka za geografijo Univerze v Ljubljani, dr. Milan Bufon in Norina Bogatec s Slovenskega raziskovalnega inštituta $\mathrm{v}$ Trstu in dr. Susanne Janschitz, M. Scmied ter D. Gral z Inštituta za geografijo Univerze v 
Celovcu. Terenska dela, predvsem anketiranja, so izvedli udeleženci Poletne univerze v Bovcu. Študentom z univerz v Mariboru, Celovcu, Vidmu, Trstu in Ljubljani gre zahvala tudi za številne ideje in spodbude pri oblikovanju posameznih členov bodoče turistične pogače (beri: ponudbe).

Karta 1: Število prenočitvenih zmogljivosti v nekaterih alpskih turističnih regijah

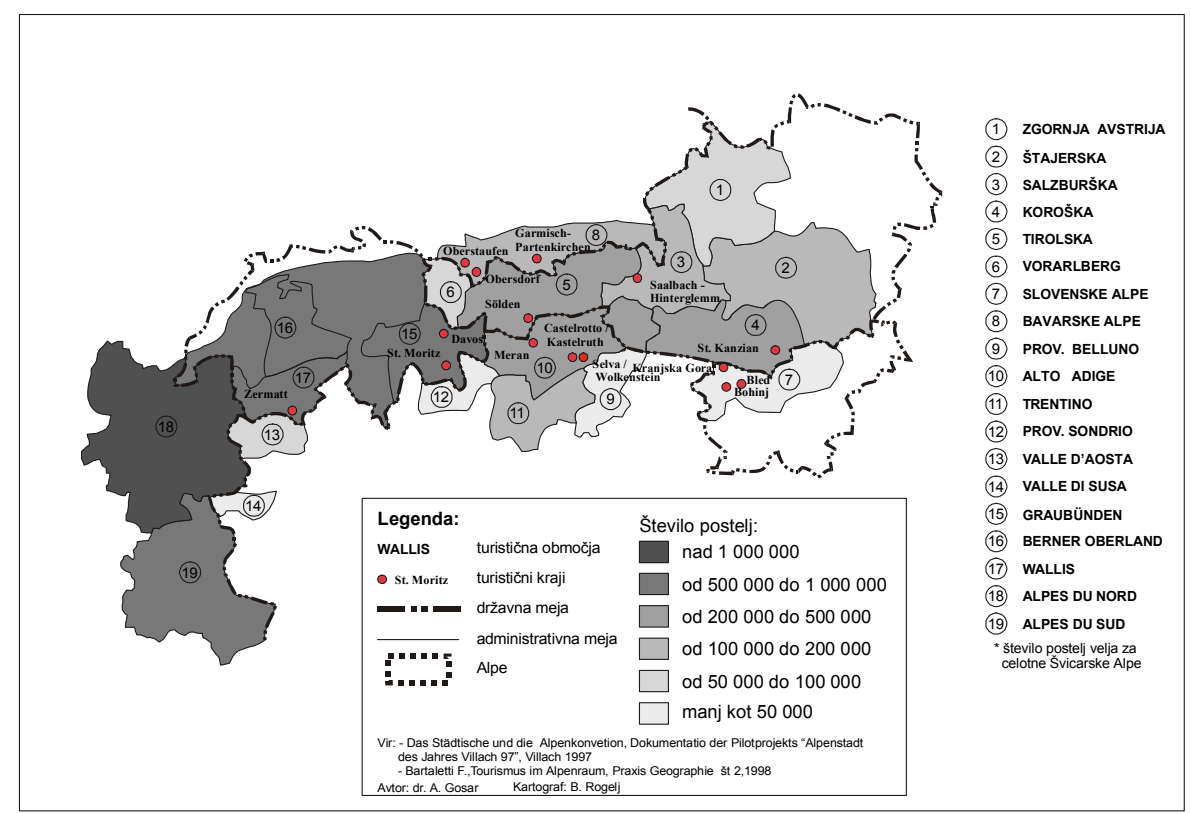

\section{RAZISKOVALNO IZHODIŠČE}

Množični turistični tokovi se vsaj od osemdesetih let dalje ne osredotočajo več le na Evropo in Severno Ameriko. Usmerili so se tudi na tista turistična območja v Aziji (Singapur, Tajska, Indonezija), na Tihem oceanu (Havaji, Polinezijska otočja, Avstralija) oziroma v Latinski Ameriki (Mehika, Karibsko otočje), kjer države spodbujajo turizem in sooblikujejo turistično politiko. Delež Evrope v svetovnem spletu turističnih ciljev se je v zadnjih dveh desetletjih zmanjšal za desetino. Konkurenčno ponudbo planinsko-gorske in alpskosmučarske izkušnje ponujajo, poleg Evrope, mnoge dežele: od Aljaske na severu preko Indije do Nove Zelandije na jugu. Relativna pocenitev letalskega prevoza, pri ponudnikih »izsiljeni« ceneni aranžmani (all inclusive) mednarodnih turističnih agencij, obdobna konkurenčna ponudba krajevnih izvajalcev turističnih storitev (hotelov, izletniških 
agencij) oziroma rezervacije $\mathrm{v}$ zadnjem trenutku (last minute) itd. oblikujejo tudi turistično ponudbo $\mathrm{v}$ gorskem svetu na globalni ravni. Tradicionalne evropske turistične dežele - tako sredozemske kot alpske - je globalna ponudba turističnih storitev postavila v položaj, ko celo za evropskega gosta niso več v prednostnem položaju. Neke vrste ekskluzivizem in monopol turističnih pokrajin, kot so to bila do pred kratkim še območja Tirolske, Bernskega visokogorja ali Francoskih Alp, je zamenjal trd boj za gosta, ki se sedaj enakovredno odloča za smučanje v kanadskem Skalnem gorovju ali na Norveškem oziroma za planinarjenje v Tatrah ali na Južnem otoku Nove Zelandije.

Karta 2: Število turističnih nočitev v nekaterih alpskih turističnih regijah

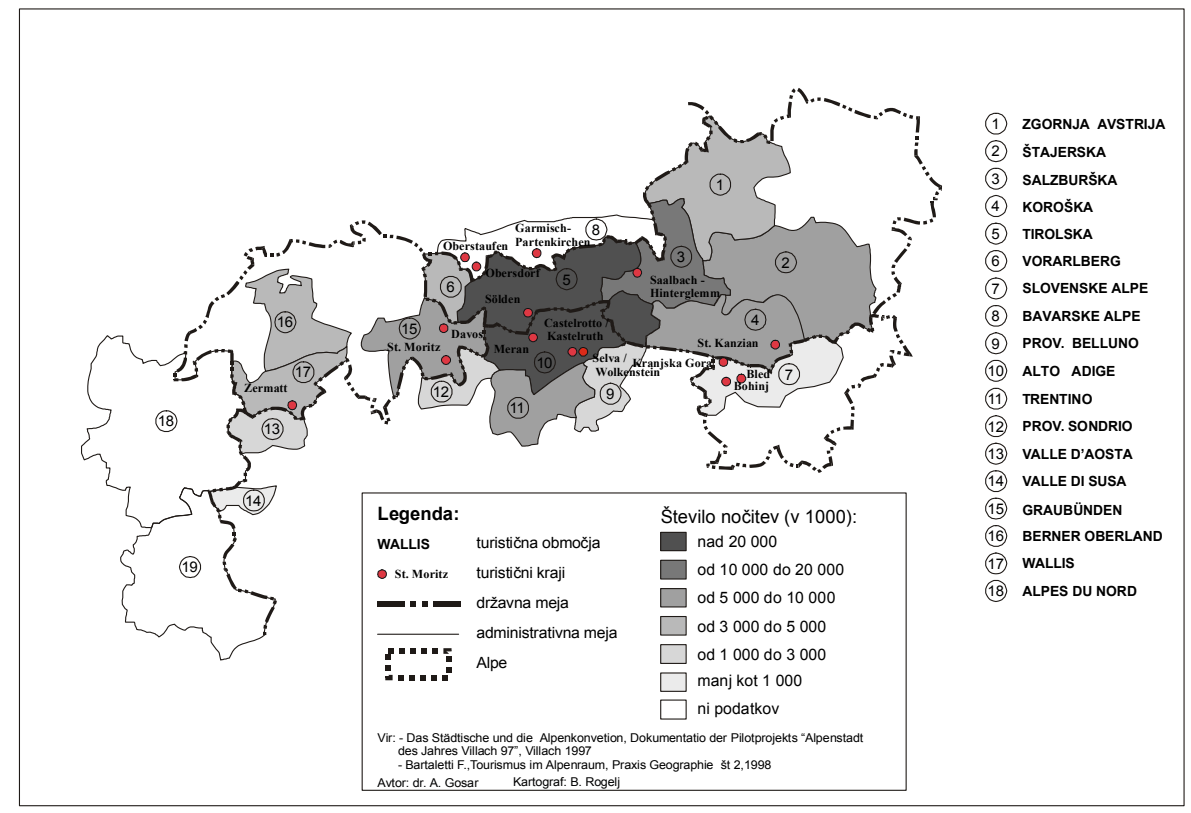


Tab.1.: Turistični obisk v Alpah

\begin{tabular}{|l|l|c|c|c|c|c|c|}
\hline & Območje & \multicolumn{2}{|c|}{ Zmogljivosti 1995 $^{\mathbf{1}}$} & \multicolumn{2}{|c|}{ Prenočevanja $^{\mathbf{2}}$} & Zasedenost $^{3}$ & Turistični indeks $^{\mathbf{4}}$ \\
\hline & & vse $^{\text {1a }}$ & hotelske & $\mathbf{1 9 9 1}$ & $\mathbf{1 9 9 5}$ & $\mathbf{1 9 9 5}$ & $\mathbf{1 9 9 5}$ \\
\hline 1. & Francoske Alpe & $2.319,7$ & 274.3 & 28.842 & 25.984 & 25.9 & 11.3 \\
\hline 2. & Italijanske Alpe & 521,1 & 398,0 & 45.245 & 47.727 & 32.8 & 11.2 \\
\hline 3. & Švicarske Alpe & 831,0 & 172,8 & 22.213 & 19.632 & 31.1 & 12.1 \\
\hline 4. & Nemške Alpe & 156,1 & 105,3 & 13.824 & 12.683 & 32.9 & 9.6 \\
\hline 5. & Avstrijske Alpe & $1.025,2$ & 562,1 & 66.972 & 61.442 & 29.9 & 19.5 \\
\hline 6. & Slovenske Alpe & 27,3 & 9,6 & 307 & 657 & 18.8 & 1.7 \\
\hline & Evropske Alpe & $4.880,4$ & $1.522,1$ & 177.403 & 168.123 & 30.5 & 12.7 \\
\hline
\end{tabular}

$1=$ ponudba postelj na turističnem trgu, $\mathrm{v} 000$

$1 \mathrm{a}=$ vključno hiše in stanovanja, ki se izdajajo $\mathrm{v}$ komercialne namene, vendar $\mathrm{z}$ izjemo zasebnih počitniških hiš in stanovanj, $\mathrm{v} 000$

2 = izključno prenočevanja $\mathrm{v}$ hotelih, $\mathrm{v} 000$

3 = zasedenost hotelskih zmogljivosti, $\mathrm{v} \%$

4 = turistični obisk merjen $v$ številu prebivalcev določenega alpskega območja

Viri: Fabrizio Barteletti: Tourismus im Alpenraum, Praxis Geographie 2/1998, 23; Werner

Bätzing: Die Alpen in neuer Sicht, Praxis Geographie 2/1998, 10; Letopis Republike

Slovenije, 1996, 400 - 410.

Vzroki za zadnja »kilava leta« v turizmu alpskega dela Evrope pa ne temeljijo le na spremembah $\mathrm{v}$ turistični ponudbi, ki je postala globalna, ampak tudi na nekaterih dejavnikih, ki so povsem območnega značaja. Osnovna ugotovitev je, da je ponudba tu, nespremenjena; po obsegu se je povečala oziroma izboljšala, nekdanjega izrazitega turističnega povpraševanja pa ni. Novi turistični cilji v Evropi in zunaj nje, $\mathrm{z}$ enako ali sorodno rekreacijsko ponudbo, ponujajo času in ciljnim skupinam primernejšo, ponavadi kakovostnejšo storitev. Obnova prenočitvenih zmogljivosti in graditev novih sta v Alpah močno odvisni od številnih omejitev. Različnost $\mathrm{v}$ ponudbi Koroške, ki ji dajejo pečat majhni obrati (»bed and breakfast «), in tisto $\mathrm{v}$ Francoskih Alpah, kjer so apartmajska naselja (IV. in V. generacija) urbanizirala visokogorsko pokrajino, je sicer dobrodošla, a v obeh primerih vprašljiva. Razmerje med ceno in kakovostjo se je $\mathrm{v}$ tradicionalnih središčih gorskega turizma poslabšalo, ekološko vprašljiv razvoj $\mathrm{v}$ visokogorju pa je trgu ponudil ceneno (prenočitveno) storitev.

V klasičnih turističnih območjih Alp, kot npr. ob koroški rivieri, je bil v sedemdesetih letih zaslužek zagotovljen vsakomur, ki se je turizma oprijel. Logično je, da so nastajala in se ohranjala mala hotelirska in druga turistična podjetja, ki pa se v sodobnosti spopadajo $\mathrm{s}$ številnimi težavami. Njihova kapitalska raven je razmeroma nizka, saj imajo le omejeno število postelj in poslujejo le nekaj mesecev v letu. Zato si ne morejo privoščiti velikih naložb v obnovo oziroma dopolnitev obratov (bazeni, igrišča), predvsem pa ne $\mathrm{v}$ inovativne, $\mathrm{v}$ regiji še nepreverjene atrakcije. Hkrati je klasična oblika turizma podjetnikom, sedaj ponavadi že ostarelim lastnikom, pomenila življenjski slog, ki se mu 
neradi, kjub slabemu iztržku, odrečejo. Redkeje se tudi odločajo za vstop v krajevno, centralizirano agencijo in/ali povezavo z nekdaj konkurenčnim podjetjem, ki je sedaj prav tako $\mathrm{v}$ škripcih. Iz te kompleksne podobe (navezanosti na konzervativno tradicijo) izvira tudi dejstvo, da svoj obrat niso pripravljeni odstopiti večji nacionalni ali nadnacionalni družbi. Delež svetovnih hotelskih verig v »turistični industriji« Alp je nasploh minimalen, ponavadi omejen na alpska pokrajinska središča (Innsbruck, Salzburg, Celovec, Graz, ...). $\mathrm{V}$ tradicionalnih območjih turizma $\mathrm{v}$ Alpah pa je še najbolj zaskrbljujoča t. i. demografska tranzicija in z njo povezana gospodarska usmerjenost in obstoj malih, avtohtonih turističnih obratov. Dediči, sinovi in hčere, nad turizmom, kot edino ali (predvsem) vzporedno gospodarsko dejavnostjo njihovega gospodinjstva, niso navdušeni. Res, turizem prinaša dohodek, a je - po njihovem mnenju - težko prigaran. Skrbeti za goste in se v celoti posvetiti gostoljubju oblikuje po eni strani delavnik, ki je daljši od osmih ur, po drugi pa zahteva zadržanost in odrekanje celotne družine. V sodobni družbi se ekonomiji ob bok enakovredno postavlja kakovost življenja!

Čas izrazite rasti turizma kot gospodarske veje je v Alpah nedvomno stvar preteklosti. Vzroke za tako stališče gre iskati $\mathrm{v}$ statističnih pokazateljih ter eksogenih in endogenih dejavnikih, ki doslej znanemu množičnemu turizmu ne obetajo nič dobrega. Demografske razmere in kakovosti življenja in okolja so v post-moderni družbi dejavniki, ki oblikujejo turistično storitev. Na trgu turističnih ponudnikov uspevajo v devetdesetih letih le tisti kraji in območja, ki imajo tradicijo oziroma znani sloves (image) in/ali se na (modno) povpraševanje odzivajo razmeroma hitro. Trg pričakuje izrazito hitro odzivanje ponudnikov na zahteve potrošnikov turističnega blaga, predvsem ob dejstvu, da vrtoglavih cenovnih razlik in »nepremagljivih" razdalij (avtocestno in sodobno (ICE-TGV-Pendolino) železniško omrežje), ki so nekdaj krojile povpraševanje po turističnih storitvah v Alpah, ni več. Le takojšnje udejanjanje rekreativnih novosti, stalno uvajanje novih privlačnosti $v$ obstoječo ponudbo in konstantna promocija kraja oziroma regije omogočajo uspeh. To velja tudi za relativno manj znano nadnacionalno alpsko regijo Tromeje s Kanalsko (v Italiji), Savsko in Soško (v Sloveniji) ter Ziljsko in Dravsko dolino (v Avstriji). Povezovanje pestre naravne ponudbe gorskega sveta, ikon vsaj treh kultur na njih stičišču in turistične infrastrukture ki je nastajala $\mathrm{v}$ treh različnih družbeno-gospodarskih sistemih, $\mathrm{v}$ enoten turistični proizvod Tromeje pomeni lahko prav slednje.

Ena od doslej še premalo izkoriščenih sestavin v turizmu je uveljavljanje prednosti, ki jih ponujajo tista območja, ki so jih družbe pred razmahom turističnega gospodarstva in urbanizacije industrijske družbe zaščitile. Narodni parki so postali biseri turistične ponudbe $\mathrm{v}$ območjih, kjer jih znajo tržiti. Tega se načrtovalci turističnega razvoja premalo zavedajo ali pa ga neustrezno vključujejo v razvojne programe. Globalno, na tržni konkurenci zasnovano gospodarstvo se je v sodobnosti primorano soočati z okolju in družbi prijaznim razvojem, ki mu mora biti tudi koncept sonaravnega razvoja v turizmu stalnica. 
Karta 2: Število prenočitvenih zmogljivosti v nekaterih alpskih turističnih regijah

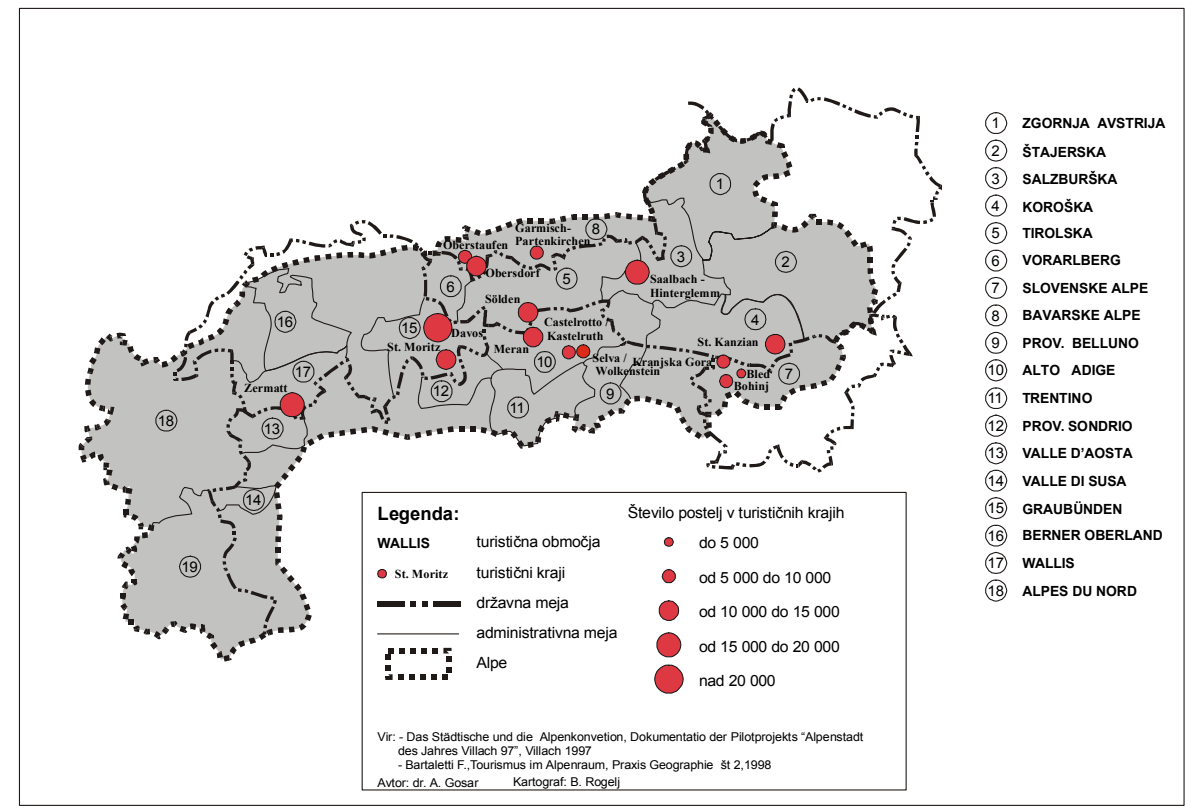

\section{RAZISKOVALNI KONCEPT}

$\mathrm{V}$ tem projektu in pričujočem članku zastavljeni koncept sonaravnega razvoja turističnega gospodarstva na območju Tromeje ni izviral iz naravovarstvenih izhodišč in tudi ni usmerjal raziskovanja $\mathrm{v}$ razmejevanje med ekološko sprejemljivim oziroma dopustnim in neustreznim. Glede na območje preučevanja, ki še zdaleč ne dosega povprečne turistične in urbane razvitosti večine turistično razvitih regij alpskega loka, se je zdelo smiselno jemati obstoječo rekreacijsko in turistično infrastrukturo kot dejstvo, ne posegati v njeno bistvo in jo, kot tako, v ponudbi povezati ter jo, v sosledju, prodajati (na turističnem tržišču) kot enovit turistični proizvod. Najpomembnejši cilj obravnavanega inovativnega pristopa je bil - po mnenju županov občin, ki so leta 1997 prisostvovali predstavitvi koncepta - v tem, da je obljubljal obstoječo turistično ponudbo povezati $\mathrm{v}$ celostno, a usmerjeno turistično ponudbo, napisano na kožo posameznim interesnim skupinam obiskovalcev. Obravnavana zamisel je, ob izničitvi državnih (in administrativnih!) meja, obljubljala namensko rabo obstoječih prostorskih virov na celotnem območju Tromeje - v Avstriji, Italiji in Sloveniji. $\mathrm{Z}$ udejanjanjem osnovnih načel zamisli bi preprečili podvajanje turistične ponudbe, 
istočasno pa bi ev. obstoječe dvojnosti preverjali na turističnem tržišču. Zaradi večjega števila rekreacijskih območij, naprav in objektov bi se zmanjševala pretirana raba posameznih, obenem pa bi se pospeševalo sodelovanje poprej ločenih gospodarstev. Obstoječim naravnim in družbenim virom bi taka zamisel (na tržišču turistične ponudbe) dajala novo kakovost in pomen.

Koncept zidakov oziroma zamisel, ki smo ji dali delovni naslov »Zrno do zrna pogača, kamen na kamen (turistična) palača« je predvideval pet glavnih faz dela:

- ugotavljanje obstoječega položaja turističnih gospodarstev v obravnavanih državah oziroma v njihovih alpskih predelih s posebnim poudarkom na stanju na Koroškem, Gorenjskem in Posočju ter Furlaniji-Julijski krajini;

- ugotavljanje in opredelitev možnih ciljnih skupin oziroma potencialnih segmentov družbe, turistov in rekreativcev ki bi jim taka ponudba na turističnem tržišču še posebej ustrezala in bi jim bogatila njihovo rekreacijsko in turistično izkušnjo;

- ugotavljanje, analiza in razvrščanje naravnih virov in kulturnih dobrin, ki so v posameznih državah sestavni del turistične ponudbe in ki $\mathrm{v}$ paketu obetajo novo kakovost;

- ugotavljanje prednosti in pomanjkljivosti regije in segmentov turistične industrije, ki stimulativno ali odbijajoče delujejo in bi jih, z načrtnim preoblikovanjem, priredili v korist predstavljene zamisli;

- oblikovanje »pogač« oziroma »zidov« - iz posameznih »zrn in zrnc«, »kamnov in kamenčkov« obstoječe turistične ponudbe po deželah - celostne regionalne oziroma enotne nadnacionalne turistične ponudbe za prihodnje stoletje.

Drug vidik inovativne sonaravnosti, ki so jo avtorji vnesli $\mathrm{v}$ zasnovo projekta je bilo dejstvo, da niso predvideli rasti turističnega čezmejnega obiska. V gospodarstvu tako priljubljeno »rast turističnega obiska« so kot vodilo zanemarili. Predvideli so le raztegnitev pred- in posezonske ponudbe, hkrati pa so se namenili obstoječi strukturi gostov in izletnikov omogočiti nova doživetja. Naslednje skupine obiskovalcev bi naj bile s tako oblikovano zamislijo še posebej nagovorjene:

- turisti, ki v regiji Tromeje že počitnikujejo in ki so jih turistične agencije ali hoteli, v katerih so prebivali, doslej usmerjali izključno na nacionalne vire turistične pondube;

- popotniki oziroma izletniki, predvsem meščani Trsta, Vidma, Ljubljane, Maribora, Celovca in Beljaka, ki se iz kakršnega koli razloga že itak odpravljajo na to območje zaradi rekreacije ali po nakupih; tem bi z dodatno turistično ponudbo obogatili enodnevno izletniško izkušnjo in jih mogoče zadržali na območju Tromeje čez vikend;

- tradicionalni obiskovalci hotelov in vikendov ob koncu tedna; njim bi ponudili oziroma zanje pripravili večplastno, čezmejno ponudbo atrakcij $\mathrm{v}$ svežnju, z izhodiščem $\mathrm{v}$ njihovem tradicionalnem kraju obiska; 
- Šolske skupine (učencev in učiteljev) iz vseh treh držav: Avstrije, Italije in Slovenije, predvsem pa iz sosednjih dežel; te skupine bi se v okviru eno- ali večdnevnega izleta seznanjale z naravno in predvsem kulturno, več-narodnostno(!) pestrostjo tega območja; - posebne skupine ljubiteljev (v Avstriji, Italiji, Sloveniji in drugod v Evropi), ki se združujejo v klubih katerih konjiček je široka paleta dejavnosti povezanih z gorskim svetom (planinarjenje, rafting in kanu, lov in ribolov ... ) oziroma $\mathrm{z}$ vojnimi spomini (napoleonske vojne, I. svetovna vojna ... ).

Osnovna filozofija tega sonaravnega razvojnega koncepta je bila $\mathrm{v}$ zametkih naravnana tako, da pokrajini ob Tromeji ni odrekala njene privlačnosti za (nadaljnji, intenzivnejši) turistični razvoj, a je v njej hkrati odkrivala in spoznavala ter $\mathrm{v}$ izvedbi upoštevala njeno ranljivost, ki je zaradi posebnosti tega dela alpskega ekosistema (kras, depopulacija ...) tu še večja kot drugod. Načelom tržnega gospodarstva koncept »Zrna do zrna ... » ni dajal prednosti. Prednosti je videl v ekonomskem partnerstvu in trans-nacionalnem sodelovanju. Humanejša in ne izključno tržno naravnana politika razvoja se je zdela snovalcem smiselnejša. A tudi dejstvo, da se tod stikajo tri svetovne kulture - slovanska, romanska in germanska - je omogočalo snovalcem razmišljati o idealnem konceptu »Nove Evrope«, ki bi jo lahko na temeljih splošnega družbenega, gospodarskega in kulturnega sodelovanja, kot zgled drugim, udejanjali prav tu. Nasilno razdvojeno ( po 1. svetovni vojni ) in po naravi pluralno kulturno pokrajino so snovalci sonaravnega razvojnega koncepta »Zrno do zrna ... » želeli zvariti v humano in (gospodarskega) preživetja sposobno komplementarno celoto. 
Tab. 2.: Turistične zmogljivosti v občinah ob tromeji Avstrije, Italije in Slovenije, 1995

\begin{tabular}{|c|l|c|c|c|c|c|c|c|c|c|}
\hline & \multicolumn{3}{|c|}{ OBČINE } & \multicolumn{3}{|c|}{ TURISTIČNI OBRATI } & \multicolumn{3}{c|}{$\begin{array}{c}\text { TURISTIČNE } \\
\text { POSTELJE }\end{array}$} & ZASEDENOST \\
\hline & & $\mathbf{1}^{* * *}$ & $\mathbf{2}^{* *}$ & $\mathbf{3}^{*}$ & $\mathbf{4}^{\mathbf{a}}$ & $\mathbf{1}^{* * *}$ & $\mathbf{2}^{* *}$ & $\mathbf{3}^{*}$ & $\mathbf{4}^{\mathbf{b}}$ & \\
\hline 1. & Arnoldstein (Podklošter) & 1 & 19 & 54 & 74 & 76 & 449 & 349 & 874 & 13.4 \\
\hline 2. & Bad Bleiberg (Plajberk) & 1 & 8 & 20 & 29 & 110 & 211 & 112 & 433 & 51.9 \\
\hline 3. & Feistritz (Bistrica v Zilji) & 0 & 1 & 10 & 11 & 0 & 5 & 74 & 79 & 16.1 \\
\hline 4. & Hohenturn (Straja vas) & 0 & 3 & 7 & 10 & 0 & 59 & 40 & 99 & 9.0 \\
\hline 5. & Nötsch (Čajna v Zilji) & 0 & 7 & 50 & 57 & 0 & 173 & 303 & 476 & 17.9 \\
\hline 6. & St. Stefan (Stebenj na Z.) & 0 & 12 & 61 & 73 & 0 & 354 & 398 & 752 & 36.9 \\
\hline & AVSTRIJA (Tromeja) & 2 & 50 & 153 & 205 & 186 & 1251 & 1276 & 2713 & 24.2 \\
\hline 7. & Bovec & 1 & 4 & 12 & 17 & 259 & 370 & 20 & 649 & 48.2 \\
\hline 8. & Kranjska gora & 6 & 14 & 27 & 47 & 1583 & 840 & 100 & 2533 & 37.6 \\
\hline & SLOVENIJA (Tromeja) & 7 & 18 & 39 & 64 & 1842 & 1210 & 120 & 3172 & 39.8 \\
\hline 9. & Chiusaforte (Skluže) & 0 & 3 & 16 & 19 & 0 & 411 & 197 & 608 & 10.5 \\
\hline 10. & $\begin{array}{l}\text { Malborghetto-Valbruna } \\
\text { (Naborjet - Ovčja vas) }\end{array}$ & 0 & 5 & 13 & 18 & 0 & 232 & 195 & 427 & 9.1 \\
\hline 11. & Pontebba (Tablja) & 0 & 5 & 9 & 14 & 0 & 206 & 19 & 225 & 15.3 \\
\hline 12. & Tarvisio (Trbiž) & 0 & 15 & 3 & 18 & 0 & 1018 & 12 & 1030 & 52.5 \\
\hline & ITALIJA (Tromeja) & 0 & 28 & 41 & 69 & 0 & 1867 & 423 & 2290 & 29.6 \\
\hline & TROMEJA & $\mathbf{9}$ & $\mathbf{9 6}$ & $\mathbf{2 3 3}$ & $\mathbf{3 3 8}$ & $\mathbf{2 0 2 8}$ & $\mathbf{4 3 2 8}$ & $\mathbf{1 8 1 9}$ & $\mathbf{8 1 7 5}$ & $\mathbf{3 0 . 2}$ \\
\hline
\end{tabular}

$1=$ hoteli z vsaj tremi zvezdicami (vsaj B kategorije)

$2=$ hoteli, moteli in penzioni z vsaj eno zvezdico ( kat. C in D )

$3=$ zasebne sobe

$4 \mathrm{a} / \mathrm{b}=$ skupno število obratov; skupno število sob

\section{REGIONALNE POMANJKLJIVOSTI (IN PREDNOSTI)}

Osrednje območje zgodovinsko pogojene alpsko-jadranske funkcionalne regije (geslo: »V srcu alpsko-jadranskega prostora «) obravnavamo v projektu kot celoto. Posebno pozornost namenjamo predstavitvi skupnih regionalnih zmogljivosti, prednosti in slabosti. V želji, odkriti vse ponudnike atrakcij, storitev in uslug, smo pod drobnogled vzeli Ziljsko in Kanalsko dolino (s Karnijskimi Alpami) ter Zgornjesavsko in Zgornjesoško dolino (z zahodnimi Julijskimi Alpami). V nadaljevanju predstavljamo splošno podobo regije in opozarjamo na tiste naravne, kulturne in organizacijske vidike, ki bi jih bilo treba $\mathrm{v}$ povezovanju spodbujati ali jih, zaradi motnje, ki jo vnašajo v prostor, omejiti oziroma odpraviti. Zaradi omejitev v obsegu članka se ustavljamo predvsem pri slednjih, medtem ko obstoječe, povezovanju prilagojene potenciale in zmogljivosti v strnjeni obliki navajamo ob koncu, ko »iz zrn mesimo (turistično) pogačo in iz kamnov zidamo (turistično) hišo«.

Posebna pozornost je veljala geostrateškemu in prometnemu položaju obravnavanega območja. Mejne države sodijo v tri vojaško različne sisteme (Italija - NATO, Avstrija - 
nevtralnost, Slovenija - NATO: Partnerstvo za mir), se vključujejo vsaj v dva družbenogospodarska bloka (Italija in Avstrija sta članici EU - Evropske zveze; Slovenija je članica CEFTA) in uradno določajo suverenost državnega ozemlja z nadnacionalnimi (Italija in Avstrija predvsem $\mathrm{z}$ Maastrichtskimi in Schengenskimi sporazumi) in nacionalnimi pravnimi akti (Slovenija). Po odpravi mejnih prehodov med Italijo in Avstrijo leta 1998 ne obstajajo uradni statistični podatki o prehodnosti tega ozemlja (število prestopov meje). Število mejnih prehodov na slovensko-italijanski meji in slovensko-avstrijski meji še vneto beležimo, pa čeprav gre pogosto le za nekajminutne postanke zaradi oskrbe z gorivom ali nakupa $\mathrm{v}$ prostocarinskih prodajalnah. Posebno smiselno se je avtorjem projekta zdelo vztrajati pri načelu v EZ že udejanjenega odpravljanja mejnih kontrolnih točk, ko smo preverjali prometno prepustnost oziroma prevoznost tega ozemlja. Ugotovili smo, da izkazuje območje Tromeje dvoje prometnih skrajnosti:

- izrazito dobro dostopnost, predvsem $\mathrm{v}$ avtocestnem in železniškem koridorju skozi Kanalsko dolino, ki ga bo v kratkem dopolnila še hitra železnica; in

- $\quad$ izrazito slabo dostopnost v Zgornji Soški dolini, ki zna biti celo nedostopna v nekaterih zimskih mesecih oziroma odrezana od posavskega dela Tromeje.

V primeru pa, da na območje Tromeje gledamo kot celoto, se zdi smiselno prezreti žrtvovanje Kanalske doline in degradacijo tamkajšnjega okolja $\mathrm{v}$ prid prometa. $\mathrm{Ob}$ ustreznem udejanjanju režima na mejah - logični cilj je njihova odprava - lahko Zgornje Posočje in vsa na prometno os Beljak - Benetke usmerjena območja, z majhnimi popravki cestnega omrežja, povežemo $\mathrm{s}$ središči kot kraji $\mathrm{v}$ regiji, kar je za naš koncept razvoja bistvenega pomena. S predrugačenjem javnega prevoza na območju Tromeje - povezava regije med seboj in regije s središči izven nje - bi bili razmisleki o drugih prometnih rešitvah odveč (električna železnica, tunel pod Vršičem, ...). V manjšem delu Tromeje, predvsem v Sloveniji, je vprašljiva tudi kakovost prometnic, saj ceste zaradi ozkega cestišča in zastarele trase (ovinki) ne omogočajo normalne potovalne hitrosti in ne dovoljujejo prehitevanj. Gledano s turističnega zornega kota primanjkuje tudi urejenih parkirnih mest, počivališč in razglednih točk.

Geomorfološki dejavniki, predvsem reliefna intenziteta je $\mathrm{v}$ alpskem svetu splošna atrakcija. Zaradi visoke stopnje ranljivosti visokogorskega kraškega sveta so $\mathrm{v}$ tej regiji visokogorja smiselno večinsko zaščitena. Med omejitvene dejavnik za razvoj turizma gre šteti tudi tektonike, saj so potresi v zadnjih dvajsetih letih kar dvakrat globoko zarezali v fizično podobo pokrajine oziroma posledično preoblikovali kulturno pokrajino. Posebno skrb, previdnost in pravno urejenost zahteva dolinska hidrološka mreža $\mathrm{z}$ obrežji. Posvetovanja z ekologi in drugimi strokovnjaki so pri načrtovanju turističnih objektov, poti in splošne rabe naravnih virov nujna. Določeno pozornost je potrebno iz ekološkega vidika posvetiti tudi dediščini stoletnega rudarjenja in predelavi svinčeve in cinkove rude. Navkljub dejstvu, da rudniki (Rajbelj in Bleiberg) ter obsežni kompleksi predelovalnih naprav (Podklošter) že celo desetletje ne obratujejo, je bila turistična podoba območja 
Tromeje prizadeta z objavo rezultatov analize prsti v Spodnji Zilji /v nemških dnevnikih in tednikih (Stern, 23, 1994, str. 44 - 52)/. Zato je obisk turističnih privlačnosti urejenih na osnovi rudarjenja - kot velja to za Terro Mystico v Bleibergu in za rudarsko-industrijski muzej v Rajblju - (̌̌e) razmeroma skromen.

Na celotnem območju Tromeje demografske razmere ne govorijo $\mathrm{v}$ prid ohranjanja avtohtonosti in posledično utrjevanja samobitnosti - tradicionalnosti navad in običajev. Ta v zgodovinskem spominu zabeležena značilnost bi znala biti turistično izredno zanimiva. Številni politični in gospodarski vetrovi so po letu 1919 dodobra prepihali stik romanskega, germanskega in slovanskega življa. Migracije so oblikovale pokrajine intenzivneje kot katerikoli drugi dejavnik demografije. Celotno območje sodi med najbolj depopulacijska območja Alp (Baetzing, 1998). Obdobno so države s političnimi ukrepi in doselitvami oziroma preselitvami oživljale, a tudi spreminjale sestavo prebivalstva ki je, posledično, preoblikovalo kulturno pokrajino po svojem (sredotežnem) okusu. S temi posegi in kasneje $\mathrm{v}$ dobiček usmerjeno gospodarsko logiko (ob državnih mejah) se je ohranjala poselitev v trgih in mestih dolinskega sveta Tromeje, medtem ko je gorsko podeželje ostarevalo in odmiralo. Pospešena industrializacija v Sloveniji in terciarizacija pri sosedah sta ob tem spodbudili deagrarizacijske procese, ki so, ob opuščanju živinoreje, sprožili ogozdovanje in s sezonsko poselitvijo (vikendi) gorskega sveta novo zvrst rekultiviranja alpske pokrajine. Ker gre pri navedenih zvrsteh poselitve za nacionalno-državno zaveden, meščanski, pogosto (državno-) indoktriniran alohton živelj, ki s tem prostorom ni živel oziroma ne pozna $\mathrm{v}$ tem prostoru zgodovinsko pogojenih temeljev večnacionalnega sobivanja, so odpori čezmejnemu sodelovanju vsakdanji pojav. Najblažja oblika tega je skepsa. Posebno dvom v projekte, ki želijo odpraviti "prastrah" enega naroda pred drugim, pa čeprav gre v tem, našem primeru za ponudbo lastne nacionalne kulture in pokrajine, oplemenitene $\mathrm{z}$ ikonami sosedov, svetovnemu turističnemu trgu.

Zgodovinske ovire ne segajo pretirano daleč $\mathrm{v}$ zgodovino. Pričenjajo se oblikovati $\mathrm{z}$ nastanki nacionalnih gibanj v 19. stoletju, dosegle so svoj višek med prvo in drugo svetovno vojno, vse od sedemdesetih let tega stoletja pa vztrajno izginjajo, simbolično s takratnim "rojstvom" transnacionalne Alpsko-jadranske delovne skupnosti". Vendar so premiki izredno počasni. Če je čutiti napredek v radovednosti pri (s)poznavanju gospodarskih prednosti sosedov (prekomejno nakupovanje oziroma oskrbovanje), pa še vedno ni čutiti želje večinskega naroda po (s)poznavanju sosedove kulture in jezika. V eni redkih analiz o znanju jezika, ki so jo opravili študentje omenjenih univerz leta 1996, se je pokazalo, da govori v posoškem delu Tromeje le približno $35 \%$ slovenskih državljanov (pogovorno) italijansko in $7 \%$ nemško, v posavskem delu te iste regije pa le $27 \%$ nemško in $12 \%$ italijansko (Academica Turistica, št. 4). Predvidevamo lahko, da je znanje slovenščine med italijanskimi in avstrijskimi državljani na tem območju, kljub slovenski manjšini, merjeno v relativnih in absolutnih vrednostih, še bistveno skromnejše. Do odprave na nacionalizmu zasnovanih ovir oziroma "prastraha" je še daleč. Posebna hiba je, da ne obstajajo zgodovinski učbeniki, pa tudi učbeniki geografije, ki bi bili zasnovani tako, da bi 
prikazovali prostor in čas $\mathrm{z}$ enotnim, za vse sprejemljivim raziskovalnim aparatom. Izobraževanje za multikulturnostno sobivanje še ni steklo. Celo v tromejnem območju Avstrije in Italije, članic Evropske zveze, ne. Ob kandidaturi za zimske olimpijske igre Treh dežel je bilo organizatorju mimogrede očitano, da ni poskrbel za sporazumevanje (trojezični slovarji: italijansko-nemško-slovensko oz. še angleško) hkrati pa mu je bila poočitana tudi regionalna razdvojenost - nekompatibilnost/nezdružljivost $v$ finančnem in državno-administrativnem pogledu. Los Angeles Times povzema mnenje Mednarodnega olimpijskega komiteja "Klagenfurt's three-country concept presents interesting aspects but also potential organizational difficulties, that with three languages and three legal systems" (LA Times, 19. 06. 1999 str. C12). Odprava teh ovir oziroma zavedanje tega daje večji pomen tudi tej zanimivi zamisli.

Nadaljna analiza prednosti in slabosti naravnih in kulturnih potencialov ter, sosledno, rekreativne in turistične ponudbe je izpostavila še naslednje pomanjkljivosti:

- $\quad$ specializacija v turistični ponudbi je redka (izjema: vodni športi na Soči, podzemni svet pod Dobračem, ...), v glavnem se enaka podvaja v vseh treh državah oziroma že na razdalji nekaj kilometrov;

- $\quad$ turistično čezmejno sodelovanje, ki bi vključevalo uporabo enotnih vozovnic v javnem prometu, uporabo kart na vseh žičnicah v regiji, plačilo z boni - voucherji agencij ali hotelov za (izbrane) gostinske in turistične storitve $v$ (gostiščih in restavracijah, hotelih in penzionih) v sosednji državi in/ali uporabo enotnih vstopnic za specifične kulturne, športne in zabavne prireditve, je šele v zametkih;

- turističnih ustanov, ki bi delovale prekomejno v predstavitvenem, informacijskem, organizacijskem in rezervacijskem smislu, ni (oz. so v nastajanju); nezadovoljiva pa je tudi regionalna, znotrajdržavna informiranost;

- $\quad$ posebno opazno pa je pomanjkanje v regiji spočetega, drznega, čezmejnega, celostnega načrtovanja - to bi moralo izhajati iz v regiji registriranih problemov in tam zasnovanih idej za njihovo odpravo; ponavadi pa se udejanjajo le načrti oziroma razvojni programi, ki jih finančno in organizacijsko spodbudi center (Ljubljana, Celovec - Dunaj, Videm Rim) in, v zadnjem desetletju, Bruselj (preko programov za oživljanje območij ob meji z Evropske zvezo: Interreg, Phare, CRPOV) ter druge zahodno-evropske vladne in nevladne (predvsem avstrijske) ustanove. 
Tab. 3.: Turistični obisk v občinah ob tromeji Avstrije, Italije in Slovenije, 1995

\begin{tabular}{|c|l|c|c|c|c|c|}
\hline \multicolumn{2}{|c|}{ OBČINE } & \multicolumn{5}{c|}{ PRENOČEVANJA } \\
\hline & & Vsa & $\begin{array}{c}\text { Zima } \\
94 / 95\end{array}$ & $\begin{array}{c}\text { Poletje } \\
1995\end{array}$ & $\begin{array}{c}\text { Tujci - } \\
\text { zima/pomlad }\end{array}$ & $\begin{array}{c}\text { Tujci - } \\
\text { poletje/jesen }\end{array}$ \\
\hline 1. & Arnoldstein (Podklošter) & 30935 & 10272 & 21055 & 66.3 & 74.8 \\
\hline 2. & Bad Bleiberg (Plajberk) & 53061 & 16004 & 37888 & 52.5 & 59.5 \\
\hline 3. & Feistritz (Bistrica v Zilji) & 4058 & 295 & 3834 & 97.3 & 88.5 \\
\hline 4. & Hohenturn (Straja vas) & 5422 & 511 & 4286 & 67.3 & 80.4 \\
\hline 5. & Nötsch (Čajna v Zilji) & 52257 & 2555 & 49488 & 94.8 & 92.5 \\
\hline 6. & St. Stefan (Štebenj na Z.) & 45883 & 5981 & 39634 & 75.3 & 81.4 \\
\hline & AVSTRIJA (Tromeja) & 191616 & 35618 & 156185 & 63.9 & 78.9 \\
\hline 7. & Bovec & 114277 & 28389 & 85888 & 64.3 & 62.2 \\
\hline 8. & Kranjska gora & 348019 & 133013 & 215006 & 59.9 & 19.1 \\
\hline & SLOVENIJA (Tromeja) & 462296 & 161402 & 300894 & 60.7 & 39.3 \\
\hline 9. & Chiusaforte (Skluže) & 23214 & 14726 & 8464 & 35.2 & 6.4 \\
\hline 10. & Malborghetto-Valbruna & 14167 & 4062 & 10105 & 18.8 & 7.3 \\
\hline (Naborjet - Ovčja vas) & & & & & 10.1 \\
\hline 11. & Pontebba (Tablja) & 12563 & 4602 & 7961 & 24.1 & 11.2 \\
\hline 12. & Tarvisio (Trbiž) & 197372 & 103200 & 94612 & 22.3 & 10.5 \\
\hline & ITALIJA (Tromeja) & 247316 & 126590 & 121142 & 23.7 & $\mathbf{4 5 . 8}$ \\
\hline & TROMEJA & $\mathbf{9 0 1 2 2 8}$ & $\mathbf{3 2 3 6 1 0}$ & $\mathbf{5 7 8 2 2 1}$ & $\mathbf{4 6 . 6}$ & \\
\hline
\end{tabular}

\section{OBLIKOVANJE REGIONALNE VEČNACIONALNE »TURISTIČNE POGAČE« IN "TURISTIČNE HIŠE"}

Naravnim danostim alpskega sveta, ki oblikujejo sezoni primerno ponudbo poleti in pozimi želi pričujoči nadnacionalni projekt "turistične pogače" vcepiti tisto značilnost, ki jo ima lahko le prostor, v katerem se stikajo kulturne dobrine treh oziroma štirih tu živečih narodov. Raziskovalci ugotavljajo, da obstaja utečeno predstavljanje kulturne dediščine na podlagi enonacionalnih, redkeje multinacionalnih prireditev oziroma srečanj. Posebno zanimanje vzbujajo prireditve, ki potekajo kot enovita prireditev na ozemljih treh držav (kolesarjenje/tek treh dežel, ... ). Množične so ponavadi tiste, ki vključujejo rekreativne oziroma športne prvine (planiški skoki, alpsko smučanje v Kranjski gori, planinsko srečanje na Peči, ...). Slabše se uveljavljajo prireditve, kjer je za razumevanje potrebno dvo- ali večjezično znanje. Multikulturnost je prisotna ponavadi $\mathrm{v}$ prireditvah cerkvenega kulturnega kroga (srečanja na Sv. Višarjih, Dobraču, ...). Številna so kulturna društva, posebno pevska, in druga združenja (npr. gasilci), ki ohranjajo avtohtono samobitnost. Posebno popularno je merjenje spretnosti $\mathrm{v}$ posameznih kategorijah dejavnosti, kot na primer v petju, pripravi gašenja, balinanju, štehvanju, ... Pogostejša so čezmejna enodnevna druženja izvajalcev programa in obiskovalcev prireditev ob cerkvenih 
praznikih. Posebno med Ziljani in Kanalci (za časa Avstro-Ogrske enoviti del Koroške), redkeje še z Gorenjci (poprej Kranjska) in Primorci (poprej Goriška-Gradiška).

$\mathrm{Na}$ podlagi vedenja o kulturnem, športnem in družabnem dogajanju in na osnovi analize naravnih danosti $\mathrm{v}$ poletju in zimi ter obstoječe turistične infrastrukture smo avtorji raziskave oblikovali pet temeljnih in enajst vzporednih (novih) turističnih proizvodov (glej Tab. 4). Tradicionalno rekreacijo v zelenju in/ali snegu nismo posebej poudarjali, definirali ali opredeljevali. Smučanju je zato namenjen en modul, ki želi spodbuditi (vsaj) organizacijsko sodelovanje med žičničarji. Izbira smučišča na območju Tromeje bi naj bila, ob ustrezni organizacijski shemi, poljubna odločitev gosta. Več vsebin je namenjenih odkrivanju izjemnih naravnih lepot $\mathrm{v}$ poletnem obdobju leta. Na prvem mestu gre omeniti tekoče (beri: deroče) vode in kanjonska ter zelena obrežja. V evropskem merilu sodita Soča in Zilja med najbolj privlačni reki za vodne športe. Nanje navezujemo tudi ribolov. Hriboviti svet Julijskih, Karnijskih in Ziljskih Alp ter Karavank vključujemo v modul pešpoti, ki niso same sebi namen oziroma ne ponujajo le panoramskih razgledov in občudovanje alpske flore in favne, temveč avtentično kulturno izkušnjo, pogosto povezano z gurmanskimi užitki (sirarstvo - Montaž, Krn) in izobraževanjem.

Oblikovalci "pogač" in "hiš", zgenetenih oziroma sezidanih iz sestavin treh kultur in alpske gorske pokrajine, smo posebno pozornost namenili zgodovinskim dogodkom in z njimi povezanimi posebnostmi tega prostora. Tudi $\mathrm{v}$ teh modulih se osnovni zamisli - na vseh področjih ponudbe poudariti prečenje državnih meja - ne želimo izneveriti. Inovativna je zamisel, da bi obiskovalce seznanili z delom, prehranjevanjem in zabavo izpred nekaj stoletij in/ali jih za dan ali dva prestavili v svet oz. delovno in življensko okolje rudarja, vojaka in planšarja. Podobno kot noč $\mathrm{v}$ kolikor toliko urejeni kaverni iz 1. svetovne vojne, bi naj tudi druge izkušnje skušale opozarjati na multikulturnost. Iz spleta spomenikov in na temelju zgodovinskih dogodkov, povezanih s 1 . svetovno vojno, smo oblikovali več itinerarijev, ki povezujejo osredje in zaledje nekdanje soške fronte. Obenem je na na pobudo avtorjev tega zapisa že zaživel program "Europeaus sine finibus", ki povezuje umetnostno-zgodovinske spomenike in naravovarstvena območja ter panoramske vršace na območju Tromeje. Izbrano etnoško dediščino in prireditve ponujamo v posebnem modulu. Mednje sodita tudi dve gurmanski izkušnji, ki združujeta dobrote kuhinj treh na Tromeji stikajočih se kultur oziroma seznanjata obiskovalce s tradicionalnimi jedmi Ziljske doline. 
Tab. 4.: Pšenična zrna in gradbeni kamni, pogače in hiše komplementarne turistične ponudbe ob tromeji Avstrije, Italije in Slovenije.

\begin{tabular}{|c|c|c|c|c|}
\hline & $\begin{array}{l}\text { "Pogače" in } \\
\text { "hiše" }\end{array}$ & $\begin{array}{l}\text { "Zrnca" in } \\
\text { "kamenčki" } \\
\text { /GESLO/ }\end{array}$ & "Kvas" in "apno" & "Voda" \\
\hline $1 \mathrm{~A}$ & $\begin{array}{l}\text { MAVRICA } \\
\text { ZGODOVIN } \\
\text { E }\end{array}$ & Europaeus sine finibus & $\begin{array}{l}\text { Začrtane etape s postanki ob } \\
\text { izbrani naravni in kulturni } \\
\text { dediščini različnih obdobij }\end{array}$ & $\begin{array}{l}\text { Pešačenje, kolesarjenje, vožnja } \\
\text { z avtom; registracija, žigi, } \\
\text { uporabna nagrada }\end{array}$ \\
\hline $1 \mathrm{~B}$ & & $\begin{array}{l}\text { Regija na prepihu } \\
\text { zgodovine }\end{array}$ & $\begin{array}{l}\text { Začrtane etape s postanki ob } \\
\text { izbrani kulturni dediščini } 19 . \text { in } \\
\text { 20. Stoletja }\end{array}$ & $\begin{array}{l}\text { Pešačenje, kolesarjenje, vožnja } \\
\text { z avtom; spominska } \\
\text { (multikult.) brošura }\end{array}$ \\
\hline $1 \mathrm{C}$ & & $\begin{array}{l}\text { Razdvajajoča } \\
\text { preteklost - skupna } \\
\text { prihodnost }\end{array}$ & $\begin{array}{l}\text { Začrtane etape s postanki ob } \\
\text { izbrani dediščini } 1 . \text { In } 2 . \\
\text { Svetovne vojne }\end{array}$ & $\begin{array}{l}\text { Pešačenje, kolesarjenje, vožnja } \\
\text { z avtom; spominski (multikult.) } \\
\text { vodnik }\end{array}$ \\
\hline $2 \mathrm{~A}$ & $\begin{array}{l}\text { TEMATSKE } \\
\text { PEŠPOTI }\end{array}$ & Brezmejno potepanje & $\begin{array}{l}\text { Dan v življenju karnijskega } \\
\text { rudarja; dan z vojakom na soški } \\
\text { fronti; potep od koče do koče; } \\
\text { med sirarji in ovčarji v Julijcih; } \\
\text { med Dobračem in Triglavom }\end{array}$ & Pešačenje; vodnik po poti, \\
\hline $2 \mathrm{~B}$ & & $\begin{array}{l}\text { Vse poti vodijo v/po } \\
\text { Evropo/i }\end{array}$ & $\begin{array}{l}\text { Razgledne točke, postajališča; } \\
\text { informacijska, oskrbna in } \\
\text { gurmanska središča treh kultur }\end{array}$ & $\begin{array}{l}\text { Avtomobilski prevoz; vodnik } \\
\text { po poti. }\end{array}$ \\
\hline $3 \mathrm{~A}$ & $\begin{array}{l}\text { ZIMSKO } \\
\text { VESELJE }\end{array}$ & $\begin{array}{l}\text { Brezmejni užitki na } \\
\text { smučeh }\end{array}$ & $\begin{array}{l}\text { Alpsko smučanje na vseh } \\
\text { smučiščih ob Tromeji; tek na } \\
\text { smučeh preko državnih meja }\end{array}$ & $\begin{array}{l}\text { Izbrana smučarska središča } \\
\text { (žičnice) in smučarske tekaške } \\
\text { poti }\end{array}$ \\
\hline $4 \mathrm{~A}$ & $\begin{array}{l}\text { POLETNA } \\
\text { DOŽIVETJA }\end{array}$ & $\begin{array}{l}\text { Modrozeleno vodovje } \\
\text { Tromeje }\end{array}$ & $\begin{array}{l}\text { Vožnja s kanuji, splavi in rafti po } \\
\text { vodah Zilje in Soče; soteskanje ... } \\
\text {; učne poti (Zelenci)... }\end{array}$ & $\begin{array}{l}\text { Vodne in obvodne dejavnosti - } \\
\text { rekreacija v zelenju in z } \\
\text { ustrezno opremo; vodstvo, } \\
\text { nadzor, razlaga... }\end{array}$ \\
\hline$\overline{4 B}$ & & $\begin{array}{l}\text { Planinarjenje brez } \\
\text { meja }\end{array}$ & $\begin{array}{l}\text { Brezmejni potep od koče do koče } \\
\text { v Julijskih, Karnijskih in Ziljskih } \\
\text { Alpah; med Dobračem in } \\
\text { Triglavom; naravovarstvena } \\
\text { izkušnja v TNP }\end{array}$ & $\begin{array}{l}\text { Enodnevne in večdnevne ture z } \\
\text { enim ali dvema izhodiščema; } \\
\text { ivodstvo in razlaga vsebine - } \\
\text { varstva naravne in kulturne } \\
\text { dediščine }\end{array}$ \\
\hline $4 \mathrm{C}$ & & Postrvi treh dolin & Ribolov v Zilji, Soči in Savi; & $\begin{array}{l}\text { Ribolovna območja in obale } \\
\text { primernih za to zvrst rekreacije; } \\
\text { piknik }\end{array}$ \\
\hline $5 \mathrm{~A}$ & $\begin{array}{l}\text { KULINARIČ } \\
\text { NE } \\
\text { DOBROTE }\end{array}$ & $\begin{array}{l}\text { Ob mizi treh kultur: } \\
\text { gastronomska pisanica }\end{array}$ & $\begin{array}{l}\text { Izkušnja romanske (italijanske), } \\
\text { germanske (avstrijske) in } \\
\text { slovanske (slovenske) kuhinje }\end{array}$ & $\begin{array}{l}\text { Podpora posebni, domači } \\
\text { gostinski ponudbi in jo - kot } \\
\text { specifiko - uvrstiti v program } \\
\text { izletov; vodnik po poti; opis } \\
\text { gastronomskih posebnosti }\end{array}$ \\
\hline $5 \mathrm{~B}$ & & $\begin{array}{l}\text { Pri ziljskem kmetu na } \\
\text { nedeljskem kosilu }\end{array}$ & $\begin{array}{l}\text { Domača, tradicionalna hrana } \mathrm{v} \\
\text { avtohtonem okolju }\end{array}$ & $\begin{array}{l}\text { Izoblikovanje mreže domačij s } \\
\text { ponudbo avtentične hrane } \\
\text { (izven mreže gostišč) }\end{array}$ \\
\hline
\end{tabular}




\section{POGLED V PRIHODNOST}

Snovalci raziskovalnega projekta prepuščajo aplikacijo omenjenih modulov turistične ponudbe oziroma »pogač« in »hiš« (turističnemu) gospodarstvu (v Avstriji, Italiji in Sloveniji). Cilj snovalcev bo dosežen, če se bo okrepil informacijski pretok in se bodo na podlagi zastavljenih modulov in/ali bodo zaradi njih nastale nove organizacijske oblike čezmejnega sodelovanja. Cilj projekta ne izključuje bogatenja turističnega dela gospodarstva, vendar želi doseči več - namreč bogatiti zamisel o transnacionalnem povezovanju na kulturnem, socialnem, infrastrukturnem, gospodarskem in ekološkem področju. To nalogo mora prevzeti določena, $\mathrm{v}$ soglasju $\mathrm{z}$ gospodarstvom ustanovljena ustanova. Ta ustanova bi morala ponujati aktualno večdeželno, večjezično in večkulturno informacijo, zagotavljala bi naj stalnost svojega delovanja, obenem pa bi naj $\mathrm{z}$ gospodarskimi ukrepi spodbujala udejanjanje zamisli o »zidakih«. Opuščeni objekti carine in policije na nekdanjih mejnih prehodih (za zdaj le na meji med Italijo in Avstrijo) lahko postanejo informacijski in predstavitveni uradi te ustanove. To bi bila lahko tudi središča splošnega regionalnega poslovanja gospodarstva ob Tromeji. Hkrati gre pričakovati, da bodo oglaševalski ukrepi te specializirane turistične ustanove propagirali celostno podobo (in ne območno naravnane!) regije in promovirali zamisel o transnacionalnem sodelovanju in (zgodovinsko pogojeni) večkulturnosti. Prodaja celostnega turističnega proizvoda (prenočišče, hrana, izleti/aktivnosti) bi naj že na začetku zaobjela zanimivosti v Avstriji, Italiji in Sloveniji. Vse akcije bi potekale računalniško centralizirano, vendar v dogovoru in sodelovanju z avtobusnimi prevozniki in žičničarji, pa tudi gostinci, hotelirji, upravljalci muzejev, galerij in drugih kulturnih spomenikov.

V kolikor želimo uresničiti pričujočo raziskovalno zasnovo in predloge so naslednji organizacijski in predstavitveni koraki gospodarstva in politikov, ki delujejo ob/na Tromeji nujni:

- $\quad$ sprožiti je treba medijsko in izobraževalno kampanjo, ki bi imela za cilj spreminjanje sicer novodobno ustaljenega, a zgodovinsko nekonsekventnega nacionalnega in nacionalističnega načina razmišljanja ljudi ob Tromeji;

- oblikovati je treba predstavitvene skupine, ki jih naj sestavljajo osebnosti iz politike, gospodarstva in javnega življenja, ki bi prebivalstvu predstavile prednosti regijsko kompleksnega in sonaravnega razvoja (turističnega) gospodarstva;

- ustanoviti je treba Svet Tromeje, transnacionalno telo, ki bi po vzoru evropskih Evroregij (Euregio) zastavilo vizijo in strategijo sodelovanja ter določalo oblike in smernice za uresničitev (skupnih) razvojnih programov, ter oblikovalo pogoje za ustanovo »regionalnega direktorja«;

- skrbeti je treba za razvoj oglaševalskih strategij in preko njih inovativno zastavljenih modelov tukajšnjega sonaravnega razvoja - v okviru političnih, gospodarskih, izobraževalnih in raziskovalnih ustanov $\mathrm{v}$ regiji in izven nje. 
Oblikovalci zamisli o »zidakih« v turizmu se zavedamo ovir, ki bodo nastopili pri udejanjanju tega koncepta. Neposredne ovire vidimo predvsem v strukturni, finančni in pravni disharmoniji, ki zaenkrat zaznamuje zatečeno prostorsko stvarnost ob Tromeji. O posrednih ovirah, ki so zgodovinsko in nacionalno pogojene in so ponekod že prerasle $\mathrm{v}$ stereotipe, smo govorili $\mathrm{v}$ tretjem poglavju. $\mathrm{S}$ pogledom, obrnjenim v prihodnost, pa se snovalci tega razvojnega koncepta zavedamo tudi možnih konfliktov, ki bodo nastali zaradi koristi posameznih uporabnikov prostora. Pri tem ne gre zanemariti dejstva, da sta turizem in rekreacija ekstenzivna, pogosto pa tudi intenzivna uporabnika prostora. $\mathrm{V}$ prid avtorskega koncepta trajne sonaravnosti pa govori (že) dejstvo, da želijo tukajšnji uporabniki (turisti) in deklarativno tudi snovalci turistične ponudbe (gospodarstvo) v veliki meri ohraniti zatečeno naravno in kulturno okolje. Zato je strah, da bi na primer izboljšava prometnega omrežja ali izgradnja turistične infrastrukture pretirano prizadela kulturno pokrajino, pogosto povsem odveč. 


\section{VIRI}

1. Baetzing W., 1998: Der Alpenraum zwischen Verstaedterung und Veroedung. Praxis Geographie 28/2. Braunschweig. Westermann, s. 4 - 10

2. Bartaletti F., 1998: Tourismus im Alpenraum - eine alpenweite Bilanz. Praxis Geographie 28/2. Braunschweig. Westermann, s. 22 - 26

3. Bizjak J., 1998: Grenzenloser Lebensraum. Planet Alpen. Villach, s. 22 - 30

4. Dolgan-Petrič M., Gosar A., 1997: Načrtovanje turističnega razvoja na območju avstrijsko-italijansko-slovenske tromeje. Aktualna znanstvena misel (=Academia Turistica 4). Nacionalno turistično združenje, Portorož, s. 83 - 109

5. Jeršič M., 1998: Pomen protokola Turizem in njegovo udejanjanje v Sloveniji. Alpska konvencija v Sloveniji. Ljubljana. RS: Ministrstvo za okolje in prostor, s. 62 - 64

6. Klavora F., 1994: Socialni in gospodarski položaj in možnosti Bovškega. Soški protokol (ur.: A. Moritsch, G. Tributsch). Celovec. Mohorjeva založba, s. 267 - 285

7. Kunaver J., 1994: Povojna usoda Bovškega v luči obmejnosti in perifernosti. Soški protokol (ur.: A. Moritsch, G. Tributsch). Celovec. Mohorjeva založba, s. 227 - 243

8. Minich R.G., 1994: Regionalna identiteta in integracija iz vidika domačinov Posočja in Kanalske doline. Soški protokol (ur.: A. Moritsch, G. Tributsch). Celovec. Mohorjeva založba, s. 181 - 191

9. Moritsch A., 1994: Človek - narodnost - meja. Soški protokol (ur.: A. Moritsch, G. Tributsch). Celovec. Mohorjeva založba, s. $141-151$

10. Moritsch A., Zimmermann F. M., 1998: Innovatives Tourismus-Baustein-Konzept im Dreilaendereck Italien, Slowenien, Oesterreich - Als Pilotprojekt fuer nachhaltige, grenzueberschreitende Tourismusentwicklung in Peripheren Regionen, Klagenfurt Graz - Wien, s. 95

11. Naprudnik M., Pobega N., 1998: Opis ciljev in vsebine protokola Turizem. Alpska konvencija v Sloveniji. Ljubljana. RS: Ministrstvo za okolje in prostor, s. 60 - 62

12. Republika Slovenija, 1996: Gostinstvo in turizem. Statistični letopis. Ljubljana. Statistični urad Republike Slovenije. s. 400 - 412

13. Zimmermann F.M., 1992: Der Blick in die touristische Zukunft: Chancen und Grenzen von Prognosen. Klagenfurter Geographische Schriften 10. Festschrift fuer Bruno Backe. Klagenfurt. Universitaet Klagenfurt, s. 209 - 227 


\title{
GRAIN BY GRAIN YIELDS BREAD, BRICK BY BRICK PRODUCES A (TOURIST) PALACE
}

\begin{abstract}
Summary
The multi-national research project focusses on the development of tourism, in accordance with the principles of sustainability in the Dreilaendereck area of Austria, Italy and Slovenia. It is a result of a two-year study of the faculty and students of the University of Klagenfurt (dr. A. Moritsch, dr. S. Janschitz, M. Scmied, D. Gral), the University of Graz (dr. F. Zimmermann), the University of Trieste (dr. M. Bufon, N. Bogatec) and the University of Ljubljana (dr. A. Gosar, B. Gradišar, M. Dolgan-Petrič).

The Dreilaendereck (The Three-Border Area) alpine environment is characterised by several mountain ridges (The Julian Alps, The Karawanken, The Carnian Alps, The Gailtaler Alps) intermontain basins and valleys as well as rivers (Sava, Soča - Isonzo, Gail Zilja, Drau - Drava). But the most striking fact is that within an area of less than onethousand square kilometres world's three major languages and cultures meet: the Romance (Italian), Germanic (Austrian) and Slavonic (Slovenian). The provinces of Krain in Slovenia, Carinthia in Austria and Friuli-Venetia Giulia in Italy, being the administrative frame for the area, have agreed to place a bid for the Winter Olympic Games in 2006. The named facts and the fact that the area is, in sense of tourism, relatively underdeveloped has provoked the following research.

Through the concept of "bricklaying" the existing tourist attractions are glued together into one single tourist product. Several topical packages combining the natural and cultural elements of the area, and disregarding the state-borders, have been put together. The major idea was not to expand existing tourist infrastructure or produce new tourist attractions. Instead, the projects points out the uniqueness of the area in its natural and cultural frame. The paper registers the existing offerings in the area of all three countries. Because of the protected natural and cultural heritage sites, like within the Triglav National Park, the winter sport ethusiast's hidden destination, like Planica (world's skijumping record) and Kranjska gora (yearly World Cup alpine skiing) and through the uniqueness of the whitewaters (Soča), the Hemingway's battlegrounds of WW 1 (The Isonzo, Caporetto) and the outstanding features of the cultural performances (Kuffenstechen - Štehvanje) and the regional cuisins of the three cultures, the transborder region of the Dreilaendereck could become recognizable within the European Alpine bow. The fact that this is an area where bilinguality in different combinations existed for centuries and where the exchange of goods allways has linked the people across mountain passes has produced this unique proposal for a transborder regional co-operation.
\end{abstract}


Several proposed packages, like the Eropeaus Sine Finibus program (mountaineering across borders and visiting several cultural heritage sites, e.g. Terra Mystica) and the White Waters Experience (Bovec), are already operational. Several others, like the Allround SkiPass, the WW1 Trail program and the Multi-Cultural Educational program are in their final stage of preparation. In the area where Slovenia, Austria and Italy meet the term "sustainable development" is understood as a direction towards mutual multi-cultural understanding and economic co-operation, disregarding the borders and political frames. 